\title{
SISTEM PENGUBURAN MASYARAKAT DESA PAO KABUPATEN GOWA
}

\author{
Syandri \\ Sekolah Tinggi Ilmu Islam dan Bahasa Arab (STIBA) Makassar \\ syandri@stiba.ac.id \\ Akhmad Hanafi Dain Yunta \\ Sekolah Tinggi Ilmu Islam dan Bahasa Arab (STIBA) Makassar \\ ahmadhanafi@stiba.ac.id
}

\begin{abstract}
Keywords : ABSTRACT

Pao Village, Funeral, Caste. $\quad$ Pao Village is one of the villages where STIBA Makassar Community Service Program (KKN) students were placed, in Bantimurung District. The purpose of this study was to elaborate burial system of caste in Pao community. Data collection in this study was through interviews with several community leaders in Pao village. The strategy employed was to give assignments to all KKN students and gather information that was found, then describe the findings in the form of a written article. The results show that the people of Pao Village are of caste level, those are: 1) Puang, 2) Karaeng, 3) Daeng, and 4) Ata (servant). Each of these levels has its own burial location and may not be mixed with the others because they are considered to have differences in social status while they live.
\end{abstract}

\section{Kata kunci :}

Desa Pao, Penguburan, Kasta

\section{ABSTRAK}

\begin{abstract}
Desa Pao adalah salah satu desa yang menjadi posko penempatan mahasiswa KKN STIBA Makassar angkatan III di wilayah Kecamatan Bantimurung. Tujuan penelitian ini adalah mendeskripsikan sistem penguburan kasta dalam kehidupan masyarakat di Desa Pao. Pengumpulan data pada penelitian ini menggunakan wawancara kepada beberapa tokoh masyarakat desa Pao. Strategi yang digunakan adalah memberikan tugas kepada seluruh mahasiswa KKN dan mencari informasi yang telah ditemukan. Kemudian mendeskripsikan hasil temuan tersebut dalam bentuk artikel tertulis. Hasil penelitian menunjukkan bahwa masyarakat Desa Pao memiliki jenjang kasta yaitu: 1) Puang, 2) Karaeng, 3) Daeng, dan 4) Ata (Pesuruh). Setiap tingkatan ini memiliki lokasi pekuburan tersendiri dan tidak boleh bercampur dengan yang lainnya karena dianggap memiliki perbedaan status sosial saat hidup.
\end{abstract}




\section{PENDAHULUAN}

Sekolah Tinggi Ilmu Islam dan Bahasa Arab (STIBA) Makassar merupakan institusi Perguruan Tinggi Agama Islam yang berkonsentrasi pada pengkaderan dai dan ulama, yang mana salah satu misi utama dari intitusi ini adalah menyebarkan ajaran Islam berdasarkan tuntunan Alquran dan Sunnah sesuai pemahaman Al-Salafusshalih melalui gerakan dakwah yang dipelopori oleh para ahlul ilmi. ${ }^{1}$ Maka dalam rangka mewujudkan misi tersebut, STIBA Makassar kemudian menjabarkan misinya secara teknis dalam program-program pengabdian kepada masyarakat, diantaranya dalam bentuk Kuliah Kerja Nyata (KKN) berbasis riset. Program KKN merupakan salah satu bentuk kegiatan perkuliahan yang dilakukan di lapangan yang berorientasi pada pembelajaran dan pemberdayaan masyarakat, ${ }^{2}$ program ini sebagai bentuk nyata keterlibatan institusi STIBA Makassar dalam upaya menumbuh kembangkan kesadaran religius yang menjadi cita-cita STIBA Makassar.

Program KKN STIBA Makassar dilaksanakan sekali dalam setahun, tepatnya diawal semester genap yaitu pada interval waktu antara bulan januari sampai dengan bulan maret, Program KKN diikuti oleh mahasiswa yang telah memenuhi semua persyaratan dan ditetapkan oleh Bidang Akademik STIBA Makassar yang berkoordinasi dengan Pusat Penelitian dan Pengabdian kepada Masayarakat (P3M) STIBA Makassar. ${ }^{3}$

Desa Pao adalah salah satu desa yang menjadi posko penempatan mahasiswa KKN STIBA Makassar angkatan III di wilayah Kec. Tombolopao Kab. Gowa Sul-Sel. Pelaksanaan KKN STIBA Makassar Angkatan III tahun 2020 dimulai pada tanggal 6 Januari 2020 sampai dengan tanggal 24 Februari 2020. Salah satu keunikan yang ada di Dusun Pao Desa Pao adalah masih lekatnya kehidupan masyarakat desa dengan keyakinan terhadap sistem klasifikasi strata sosial atau sistem kasta dalam kehidupan masyarakat. Bahkan sistem kasta dalam masyrakat dusun Pao memberikan pengaruh yang cukup kuat terhadap sistem penguburan masyarakat ketika telah meninggal dunia.

Oleh karena itu, dalam penelitian ini, kami memfokuskan pada pembahasan sistem pekuburan sesuai kasta dalam masyarakat dusun Pao. Pengumpulan data pada penelitian ini menggunakan wawancara kepada beberapa tokoh masyarakat dusun Pao. Strategi yang digunakan adalah memberikan tugas kepada seluruh mahasiswa KKN dan mencari informasi yang telah ditemukan. Kemudian mendeskripsikan hasil temuan tersebut dalam bentuk artikel tertulis.

\footnotetext{
1 Sekolah Tinggi Ilmu Islam dan Bahasa Arab (STIBA) Makassar, Visi misi, https://stiba.ac.id//tentangstiba/visi-misi/ (9 April 2020)

${ }^{2}$ P3M STIBA Makassar. Buku Panduan KKN STIBA Makassar Angkatan II Tahun 1440 H/ 2018 M (Makassar: STIBA Makassar, 2018), h.3.

${ }^{3}$ Tim Penyusun. Buku Panduan KKN STIBA Makassar Angkatan II Tahun 1440 H/2018 M, h.3.
}

Syandri, Akhmad Hanafi Dain Yunta. Sistem Penguburan Masyarakat ... 
WAHATUL MUJTAMA': Jurnal Pengabdian Masyarakat

Vol. 1, No. 1 (2020) : Hal. 33-41

Website: https://journal.stiba.ac.id

\section{Sejarah Munculnya Desa Pao}

Dalam buku profil desa Pao disebutkan bahwa sejarah desa Pao dahulu kala nampaklah sekumpulan tanah dengan seekor ayam putih, tanah ini sekarang bernama Gunung Bawakaraeng, bertahun tahun lamanya pada zaman dahulu bumi ini masih lautan, semakin hari air laut itu semakin surut, sehingga nampaklah semua daratan yang ada di muka bumi ini.

Menurut sejarah, di sebuah perkampungan kecil yang ditumbuhi oleh pohon Mangga, ada seorang Tumanurung dari Bawakaraeng yang bernama Tette Dg Mangngala. Beliaulah yang membangun perkampungan kecil ini yang diberinama Pao yang berarti Mangga. Karena ditanah Pao ini banyak ditumbuh pohon Mangga dan di tanah ini pula Tumanurung tersebut "Appau-pau” artinya berkata. Kata Appau-pau inilah yang menjadi dasar sehingga perkampungan ini diberi nama Pao. Setelah tercium oleh pihak kerajaan Gowa bahwa dihulu sana telah berdiri sebuah perkampungan yang aman, damai, dan sejahtera maka diutuslah beberapa panglima perang dari keerajaan Gowa untuk memerangi Butta Pao (tanah Pao). Akan tetapi pasukan dari Gowa tersebut kalah dari pasukan Butta Pao. Setelah beberapa kali dilakukan penyerangan terhadap Butta Pao, pasukan kerajaan Gowa tetap tidak mampu mengalahkan Butta Pao sehingga kerajaan Gowa mengakui Pao sebagai daerah yang kuat, maka berdirilah kerajaan Pao dengan raja pertama adalah tette Dg Mangngala yang bergelar Puangta Ri Pao.

Di masa kepemimpinan beliau, rakyat Pao menjadi aman, damai, dan sejahtera. Kerajaan Pao ini menaungi beberapa Gallarang. Gallarang yang dimaksud dalam masyrakat Pao adalah pimpinan wilayah yang dikuasai oleh kerajaan Pao. Gallarang ini terdiri dari Enam Gallarang yaitu gallarang Pao, Gallarang Baringang, Gallarang Tonasa, Gallarang Mamampang, Gallarang Suka, dan Gallarang Balassuka. Semua wilayah ini dipimpin oleh seorang Galla yang sekarang ini berarti Kepala Desa.

Dalam pemerintahan Puangta Ri Pao beliau didampingi oleh seorang Bongki. Bongki adalah pemangku adat, atau dewan yang mengurusi pergantian puanta dan upacara-upacara adat. Ada pula pendamping raja yaitu Pakbarambang yang bertugas untuk menjaga keamanan kerajaan pao. Setelah Belanda datang dan menjajah Indonesia, kerajaan Pao pun tak luput dari invasi tersebut. Pusat pemerintahan dipindahkan ke Tombolo dan melantik A. Baso Makkupalle sebagai Puanta Ri Pao. Seiring berjalannya waktu dan berkembanganya Ilmu Pengetahuan, maka terbitlah aturan-aturan tentang pengelolaan pemerintahan dalam suatu daerah atau wilayah yang dituangkan dalam Undang-undang oleh pemerintah. Dengan adanya Undang-undang tentang pemerintahan desa, maka kerajaan Pao berubah nama menjadi desa Tamaona dan diangkat sebagai kepala desa pertama adalah Karaeng Teya. ${ }^{4}$

${ }^{4}$ Pemerintah desa pao, Buku Profil Desa Pao (tidak diterbitkan). h. 1-2. 
WAHATUL MUJTAMA': Jurnal Pengabdian Masyarakat

Vol. 1, No. 1 (2020) : Hal. 33-41

Website: https://journal.stiba.ac.id

\section{Sistem Keyakinan Masyarakat Desa Pao}

Pada awalnya, masyarakat desa Pao menjadikan para raja sebagai sumber pengetahuan. Keyakinannya bertumpu pada apa yang disampaikan oleh para raja yang memerintah. Sehingga nampak keyakinan warga lebih banyak terpengaruh dengan kayinan animisme dimana banyak tempat di sekitar desa yang dikeramatkan atau dipercayai memiliki kekuatan gaib. Menurut bapak Harun bahwa desa Pao adalah merupakan desa tua dimana pekuburan dibagi sesuai dengan keturuan. Warga desa ini dahulunya dikenal memiliki paham animisme yang kuat, yang kiblat masyarakat mengarah ke Tanah lompoa. ${ }^{5}$ Demikian juga disampaikan oleh salah seorang warga desa Pao bahwa dahulunya desa Pao merupakan tempat bersarangnya Doti (semacam praktek sihir dan perdukunan) dan merupakan sarang banyaknya mantra-mantra.

Adapun menurut bapak Aziz sistem keyakinan masyarakat Pao masih ada hubungan erat dengan agama Hindu. Beliau mencontohkan adanya sistem kasta dalam masyarakat yang diterapkan oleh raja untuk tujuan membedakan status sosial mereka. Mereka mengistilahkan raja dengan kasta Puang yang juga merupakan kasta tertinggi.

Dalam penerapan sistem kerajaan, mereka menerapkan dengan sistem adat istiadat, jadi di setiap desa yang merupakan wilayah kekuasaan raja ditempatkan seorang wakil di rumah adat, mereka bertugas melaporkan kejian-kejadian di daerah masingmasing. (Wawancara, Azis, tokoh Masyarakat)

Bersamaan dengan semakin terbukanya desa, komunikasi antar desa juga sudah terjalin dengan baik, ditambah dengan semakin majunya teknologi, komunikasi dan transportasi, sedikit demi sedikit keyakinan masyarakat mulai memudar. Walaupun tidak dipungkiri bahwa masih ada yang masih meyakini mitos-mitos yang tersebar di tengah masyarakat desa.

\section{PEMBAHASAN}

\section{Sistem Penguburan Masyarakat di Desa Pao}

Desa Pao memiliki sistem kehidupan yang unik, dimana masyarakat dibagi kedalam beberapa kasta (tingkatan). Masing-masing kasta memiliki tugas pokok dalam kehidupan sehingga juga memiliki konsekuensi-konsekuensi hidup yang berbeda satu dengan yang lainnya. Bahkan setelah meninggal pun perbedaan kasta ini sangat akan mempengaruhi prosesi penyelenggaraan jenazah dan penguburannya. Dari informasi yang ditemukan, sistem ini mulai ditetapkan oleh raja pertama yang memerintah kerajaan Pao yang merupakan kerajaan independen terpisah dari kerjaan Gowa. ${ }^{6}$

Dalam kerjaan Pao masyarakat dibagi ke dalam Empat jenjang strata sosial yaitu: 1) Puang, 2) Karaeng, 3) Daeng, dan 4) Ata (Pesuruh). Setiap tingkatan ini memiliki lokasi pekuburan tersendiri dan tidak boleh bercampur dengan yang lainnya.

\footnotetext{
${ }^{5}$ Wawancara, Tombolopao. Harun. Ketua Muhammadiyah Cab. Tombolopao

${ }^{6}$ Wawancara, Tombolopao. Suardi, S.Pd. M.Pd Pemilik Yayasan Mts, MA Pao
} 
WAHATUL MUJTAMA': Jurnal Pengabdian Masyarakat

Vol. 1, No. 1 (2020) : Hal. 33-41

Website: https://journal.stiba.ac.id

Kasta Puang yang dianggap mendapatkan mandat langsung dari raja pertama dan keturunannya memiliki pekuburan yang paling spesial. Tidak boleh dicampuri oleh kuburan yang lainnya. Golongan puang yang lain, adalah yang tidak mendapatkan langsung mandat dari keturunan raja. Kasta Puang inilah yang ditemukan kuburan mereka bercampur dengan dari kasta karaeng. Khusus masyarakat dari tingkatan Ata (pembantu) tidak boleh dikuburkan di pekuburan kasta yang ada diatasnya. Jika ini ditemukan maka dengan terpaksa akan dipindahkan. ${ }^{7}$

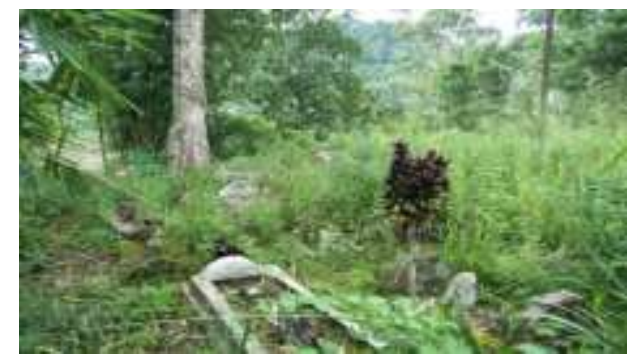

Gambar 1. Lokasi Pekuburan Bongki untuk Puang

Kasta yang paling tinggi untuk pribumi adalah Puang adapun pendatang kasta tertinggi mereka adalah Karaeng. Warga yang memiliki status Karaeng adalah nonpribumi yang menikah dengan pribumi dari kasta Puang. Walaupun secara status sosial tinggi, Karaeng tidak bisa membuat kebijakan dalam masyarakat karena hanya dari kasta Puang yang boleh membuat sebuah keputusan. ${ }^{8}$

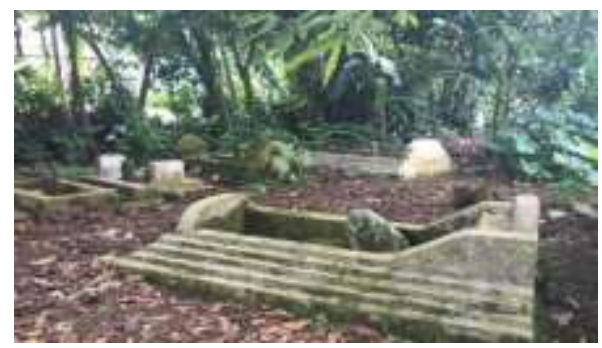

Gambar 2. Lokasi Pekuburan Baruga Toaia untuk Karaeng

Saking pentingnya bagi masyarakat Pao untuk dikuburkan di desanya sendiri terkhusus bagi warga dari keturuan Puang, jika meninggal di luar desa maka jenazahnya akan dikembalikan untuk dikebumikan di desa Pao. ${ }^{9}$ Sistem kasta ini hanya berlaku pada saat sistem kerajaan masih berjalan. Pada saat pemerintah masuk, sistem ini tidak berlaku lagi. Apatah lagi ketika status ekonomi masyarakat sudah mulai merata diantara warga. Bahkan yang memiliki kasta Puang dan memiliki Ata (pesuruh) itu tidak lagi berani memanggil nama pesuruhnya dengan nama Ata apalagi ketika Ata pun sudah memiliki

\footnotetext{
${ }^{7}$ Wawancara, Tombolopao, Firman Arifin S.Sos. Sekdes Desa Pao.

${ }^{8}$ Wawancara, Tombolopao, Azis, tokoh Masyarakat

${ }^{9}$ Wawancara, Tombolopao, Puang Lewa' Tokoh Masyarakat.
} 
WAHATUL MUJTAMA': Jurnal Pengabdian Masyarakat

Vol. 1, No. 1 (2020) : Hal. 33-41

Website: https://journal.stiba.ac.id

ekonomi yang mapan. Adapun pemilahan warga berdasarkan kasta saat penguburan itu masih berlaku. ${ }^{10}$

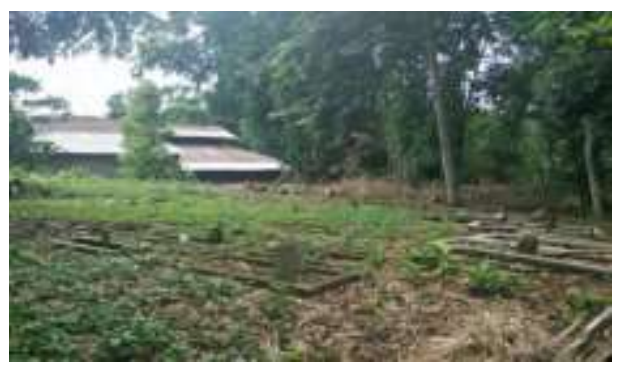

Gambar 3. Lokasi Pekuburan Bantaeng untuk Ata

Dalam penyelenggaraan jenazah kasta-kasta ini memiliki cara yang berbeda. Jika jenazah dari kasta atas, maka akan dilakukan prosesi-prosesi yang lebih meriah dari kasta yang lebih rendah. Seperti penyembelihan hewan bagi kelaurga dari kasta Puang. Dusun Pao desa Pao yang tidak terlalu luas, terdapat Delapan lokasi pekuburan, dengan detail sebagai berikut:

1. Pekuburan Bongki untuk Puang

2. Pekuburan Bonto untuk Puang

3. Pekuburan Pamanreang untuk Puang

4. Pekuburan Taipa

5. Pekuburan Buakkang Mata untuk Ata

6. Pekuburan Bantilang untuk Puang

7. Pekuburan Bantaeng untuk Ata

8. Pekuburan Baruga Toaia untuk Karaeng

\section{Perspektif Hukum Islam terhadap Sistem Penguburan sesuai Kasta pada Masyarakat Dusun Pao Desa Pao}

Melihat sistem pekuburan di dusun Pao desa Pao memang sangat unik, dimana pekuburan tersebar di beberapa lokasi dalam kampung yang tidak begitu luas. Sistem yang terapkan, jika ditinjau dengan tinjauan hukum Islam memiliki beberapa masalah.

Pertama: ini menunjukkan bahwa ada sistim kasta dalam masyarakat dusun ini. Sehingga berdampak pada terjadinya terklasifikasinya masyarakat ke dalam beberapa tingkat. Sementara dalam islam tidak dikenal sistem seperti ini. Sangat banyak ayat dan hadis Rasulullah yang menjelaskan akan persamaan derajat antara semua element umat Islam. Tidak ada perbedaan antara kaya dan miskin, antara pejabat dan rakyat jelata. Rasûlullâh Shallallahu 'alaihi wa sallam bersabda:

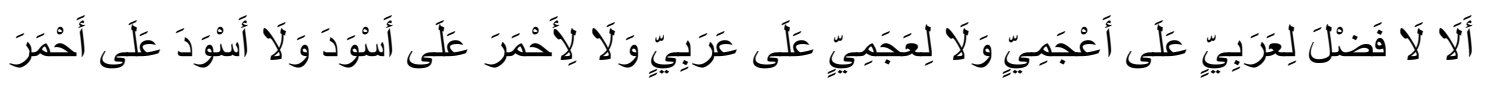

${ }^{10}$ Wawancara, Tombolopao, Azis, Tokoh Masyarakat 
Ketahuilah bahwa tidak ada keutamaan bagi orang 'Arab di atas orang 'Ajam (non 'Arab), tidak keutamaan bagi orang ajam di atas orang arab, juga bagi yang berkulit merah di atas yang berkulit hitam atau bagi yang berkulit hitam di atas yang berkulit merah kecuali dengan sebab ketakwaan.

Dalam Q.S. Al Hujarat/48: 13.

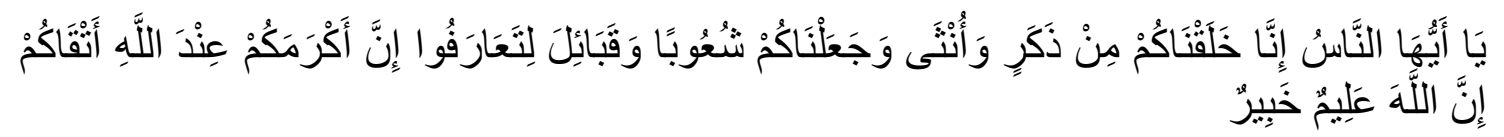

"Hai manusia, sesungguhnya Kami menciptakan kamu dari seorang laki-laki dan seorang perempuan dan menjadikan kamu berbangsa-bangsa dan bersuku-suku supaya kamu saling kenal mengenal. Sesungguhnya orang yang paling mulia di antara kamu di sisi Allah ialah orang yang paling bertakwa di antara kamu. Sesungguhnya Allah Maha Mengetahui lagi Maha Mengenal." 12

Kedua: Islam telah mengatur dengan lengkap tata cara penyelenggaraan jenazah sesuai dengan tuntunan Rasulullah. Hal ini Secara umum agar tidak terjadi berbagai penyimpangan dalam proses pnguburan tersebut. Karena jika otoritas prosesi penyelenggaraan jenazah ini diberikan sepenuhnya kepada masing-masing individu ataupun kelompok, maka akan berdampak bervariasinya tata cara penyelenggaraan tersebut, yang pada akhirnya akan memecah belah umat. Sedangkan Islam datang untuk mempersatukan semua umat manusia dari seluruh adat istiadat dan kebiasaan.

Oleh sebab itu sebagaiamana dijelaskan oleh Abdullah bin Jarullah dalam bukunya Tata Cara Mengurus Jenazah beliau menyebutkan dalam Islam proses penyelenggaraan jenazah sampai proses penguburan telah diatur dengan baik. Mulai dari memandikan, mengafani, mensalatkan dan menguburkan. ${ }^{13}$

Ketiga: sistem penguburan jenazah di dusun Pao, keluar dari tujuan utama pensyariatan penguburan di satu tempat yang sama. Dimana Islam mengatur bahwa sebaiknya penguburan jenazah lebih baiknya disatukan di pekuburan umum kaum muslimin agar jenazah bisa mendapatkan kebaikan lebih banyak seperti doa para penjenguk. ${ }^{14}$ Kecuali para nabi mendapatkan kekhsususan, dimana mereka dikuburkan

\footnotetext{
${ }^{11}$ Aḥmad Ibn Hanbal, Musnad Imām Āḥmad Ibn Hanbal, (Muassasah Al Risālah, 1999). h. 474.

${ }^{12}$ Kementrian Agama, Al-Qur'an dan

Terjemahnya (Depok, Sabiq, 2012), h. 515

${ }^{13}$ Abdullah bin Jarullah bin Ibrahim Al Jarullah, Tata Cara Mengurus Jenazah, terj. Abullah Haidir (Riyadh, Kantor Kerjasama Da;wah Bimbingan dan Penyuluhan bagi Pendatang: t.t), h. 4.

${ }^{14}$ Wizārah Al Auqāf wa Al Syu'ūn Al Islāmiyah Al Kuwaituyyah, Al Mausūah Al Fiqhhiyyah Al Kuwaitiyyah, Vol. 21 (cet. II, Kuwait: Dār Al Salāsil, 1427), 9.
}

Syandri, Akhmad Hanafi Dain Yunta. Sistem Penguburan Masyarakat ... 
WAHATUL MUJTAMA': Jurnal Pengabdian Masyarakat

Vol. 1, No. 1 (2020) : Hal. 33-41

Website: https://journal.stiba.ac.id

ditempat mereka meninggal. ${ }^{15}$ Dalam beberapa referensi fikih Islam juga disebutkan bolehnya menguburkan jenazah sesama keluarga dekat dengan alasan adanya contoh dari Rasulullah dan juga akan memudahkan ziarah dan akan lebih memunculkan rasa kasih sayang kepada mereka. ${ }^{16}$ Akan tetapi ini berbeda dengan apa yang temukan di Dusun Pao yang memisahkan pekuburan bukan karena alasan yang telah disebutkan, akan tetapi lebih pada alasan status sosial.

\section{KESIMPULAN}

Asal Muasal desa Pao adalah dari salah satu yang disebut sebagai Tumanurung yaitu Tette Dg Mangngala. Beliaulah yang membangun perkampungan kecil ini yang diberinama Pao yang berarti Mangga. Karena ditanah Pao ini banyak ditumbuh pohon Mangga dan di tanah ini pula Tumanurung tersebut "Appau-pau” artinya berkata. Kata Appau-pau inilah yang menjadi dasar sehingga perkampungan ini diberi nama Pao.

Masyarakat desa Pao seluruhnya menjadikan para raja sebagai sumber pengetahuan dan keyakinannya bertumpu pada apa yang disampaikan oleh para raja yang memrintah. Sehingga nampak keyakinan warga lebih banyak terpengaruh dengan kayinan animisme dimana banyak tempat di sekitar desa yang dikeramatkan atau dipercayai memiliki kekuatan gaib.

Desa Pao memiliki sistem kehidupan yang unik, dimana masyarakat dibagi kedalam beberapa kasta (tingkatan). Masing-masing kasta memiliki tugas pokok dalam kehidupan sehingga juga memiliki konsekuensi-konsekuensi hidup yang berbeda satu dengan yang lainnya. Bahkan setelah meninggal pun perbedaan kasta ini sangat akan mempengaruhi prosesi penyelenggaraan jenazah bahkan penguburannya. Dalam kerjaan Pao masyarakat dibagi ke dalam Empat jenjang kasta yaitu: Pertama: Puang, Kedua: Karaeng, Ketiga: Daeng, Keempat: Ata (Pesuruh).

\section{DAFTAR PUSTAKA}

Abdullah bin Jarullah bin Ibrahim Al Jarullah, Tata Cara Mengurus Jenazah, terj. Abullah Haidir. Riyadh, Kantor Kerjasama Da;wah Bimbingan dan Penyuluhan bagi Pendatang: t.t.

Aḥmad Ibn Ḥanbal. (1999) Musnad Imām Āḥmad Ibn Hanbal. Muassasah Al Risālah.

Ali, M. M. (2001). The Concept of Modernization: An Analysis of Contemporary Islamic Thought. American Journal of Islamic Social Sciences, Vol. 14, No.1 (Spring 2001): p.13-26.

Kementrian Agama. (2012). Al-Qur'an dan Terjemahnya. Depok, Sabiq.

\footnotetext{
${ }^{15}$ Muḥammad ibn 'īsā Abū 'Īsā Al Tirmiż̀̄, Al Jāmi' Al Ṣaḥih Sunan Al Tirmiż̀̄ Juz III, hadīì no. 1018 (Bairūt, Dār Ihyā Al Turāis, 1975 ), h. 338.

${ }^{16}$ Wahbah Al Zuhailī, Fiqh Al Islām wa Adillatuhū Vol. 2, (cet. III; Dimisyq, Dār Al Fikr, 1985). h. 661.
}

Syandri, Akhmad Hanafi Dain Yunta. Sistem Penguburan Masyarakat ... 
WAHATUL MUJTAMA': Jurnal Pengabdian Masyarakat

Vol. 1, No. 1 (2020) : Hal. 33-41

Website: https://journal.stiba.ac.id

Muhammad ibn 'īsā Abū 'Īsā Al Tirmiżī, Al Jāmi’ Al Ṣaḥih Sunan Al Tirmiżī (1975). Juz III, hadīis no. 1018 .Bairūt, Dār Ihyā Al Turāś,.

Profil Desa Pao. Kantor Desa Pao (tidak diterbitkan)

P3M STIBA Makassar. (2018). Buku Panduan KKN STIBA Makassar Angkatan II Tahun 1440 H/ 2018 M, Makassar: P3M STIBA Makassar.

Sekolah Tinggi Ilmu Islam dan Bahasa Arab (STIBA) Makassar, Visi misi, https://stiba.ac.id//tentangstiba/visi-misi/ (9 April 2020).

Wahbah Al Zuhailī, Fiqh Al Islām wa Adillatuhū (1985) jilid 2, (cet. III; Dimisyq, Dār Al Fikr.

Wizārah Al Auqāf wa Al Syu'ūn Al Islāmiyah Al Kuwaituyyah (1427). Al Mausūah Al Fiqhhiyyah Al Kuwaitiyyah, Vol. 21 (cet. II, Kuwait: Dār Al Salāsil. 